\title{
Genetic diversity of Plasmodium vivax in Kolkata, India
} Jung-Ryong Kim ${ }^{1}$, Mallika Imwong*1, Amitabha Nandy², Kesinee Chotivanich ${ }^{1}$, Apichart Nontprasert ${ }^{1}$, Naowarat Tonomsing ${ }^{1}$, Ardhendu Maji ${ }^{2}$, Manjulika Addy ${ }^{2}$, Nick PJ Day ${ }^{3}$, Nicholas J White ${ }^{1,3}$ and Sasithon Pukrittayakamee ${ }^{1,4}$

Address: ${ }^{1}$ Department of Clinical Tropical Medicine, Faculty of Tropical Medicine, Mahidol University, Bangkok, Thailand, ${ }^{2}$ Department of Parasitology and Protozoology, the Calcutta School of Tropical Medicine, Kolkata, India, ${ }^{3}$ Centre for Clinical Vaccinology and Tropical Medicine, Churchill Hospital, Old Road, Headington, Oxfordshire OX3 7LJ, UK and ${ }^{4}$ The Royal Institute of Thailand, Grand Palace, Bangkok, Thailand

Email: Jung-Ryong Kim - lukimjy@yahoo.com; Mallika Imwong* - noi@tropmedres.ac; Amitabha Nandy - centromap@yahoo.com; Kesinee Chotivanich - nok@tropmedres.ac; Apichart Nontprasert - apichart@tropmedres.ac; Naowarat Tonomsing - tsnao@yahoo.com; Ardhendu Maji - centromap@yahoo.com; Manjulika Addy - centromap@yahoo.com; Nick PJ Day - nickd@tropmedres.ac; Nicholas J White - nickw@tropmedres.ac; Sasithon Pukrittayakamee - sasithon@tropmedres.ac

* Corresponding author

Published: 14 August 2006

Malaria Journal 2006, 5:71 doi:10.1 186/1475-2875-5-7I
Received: 16 February 2006

Accepted: 14 August 2006

This article is available from: http://www.malariajournal.com/content/5/I/7I

(c) 2006 Kim et al; licensee BioMed Central Ltd.

This is an Open Access article distributed under the terms of the Creative Commons Attribution License (http://creativecommons.org/licenses/by/2.0), which permits unrestricted use, distribution, and reproduction in any medium, provided the original work is properly cited.

\begin{abstract}
Background: Plasmodium vivax malaria accounts for approximately $60 \%$ of malaria cases in Kolkata, India. There has been limited information on the genotypic polymorphism of $P$. vivax in this malaria endemic area. Three highly polymorphic and single copy genes were selected for a study of genetic diversity in Kolkata strains.

Methods: Blood from I5I patients with P. vivax infection diagnosed in Kolkata between April 2003 and September 2004 was genotyped at three polymorphic loci: the $P$. vivax circumsporozoite protein (pvcs), the merozoite surface protein I (pvmspl) and the merozoite surface protein 3-alpha (pvmsp3-alpha).

Results: Analysis of these three genetic markers revealed that $P$. vivax populations in Kolkata are highly diverse. A large number of distinguishable alleles were found from three genetic markers: II for pvcs, 35 for pvmspl and 37 for pvmsp3-alpha. These were, in general, randomly distributed amongst the isolates. Among the $15 \mid$ isolates, 142 unique genotypes were detected the commonest genotype at a frequency of less than $2 \%(3 / I 5 I)$. The overall rate of mixed genotype infections was $10.6 \%$.

Conclusion: These results indicate that the $P$. vivax parasite population is highly diverse in Kolkata, despite the low level of transmission. The genotyping protocols used in this study may be useful for differentiating re-infection from relapse and recrudescence in studies assessing of malarial drug efficacy in vivax malaria.
\end{abstract}

\section{Background}

Malaria remains one of the most important communica- ble diseases in the world. Despite enormous control efforts over many decades malaria is still a significant 
health problem. It is estimated that around 300-500 million cases occur each year with one to three million deaths. The problem is compounded by multiple drug resistance in Plasmodium falciparum and chloroquine resistance in Plasmodium vivax [1]. The global burden of malaria due to $P$. vivax is $70-80$ million cases annually. Vivax malaria is usually a non-lethal infection but its prolonged and recurrent infection can have major deleterious effects on personal well-being, growth and on the economic performance at the individual, family, community and national levels [2]. The recent emergence of chloroquine-resistant strains is of great concern [3-5].

P. vivax causes about $60-65 \%$ of all malaria infections in India $[6,7,42]$. The frequency of relapse after a standard course of chloroquine and primaquine treatment is 23$40 \%$ depending on the duration of follow-up in India $[7,36]$. P. vivax and P. falciparum are prevalent in all age groups but their prevalence is highly seasonal and differs between the species; longitudinal studies in India show a winter peak for $P$. falciparum and a summer peak for $P$. vivax $[7,8]$. Chloroquine appears to remain an effective drug in the treatment of $P$. vivax malaria in Kolkata [6].

The majority of studies on the genetic structure of Plasmodium have focused on $P$. falciparum, using polymorphic markers such as the merozoite surface protein-1(msp-1), 2 (msp-2), glutamate-rich protein (glurp) $[9,14]$. A similar approach has been adopted for $P$. vivax but it has been less well-studied at the molecular level than P. falciparum [18]. Three polymorphic $P$. vivax genes have been widely used for molecular epidemiological studies. The pvcs gene has a central repeat domain that varies in sequence and number of repeat units $[10,41]$. Two major types, VK 210 and VK247, have a worldwide distribution and four subtypes from VK210 and two subtypes from VK 247 can be differentiated by restricted enzyme digestion to show polymorphisms in both the pre- and post- repeat region [28]. The pumsp 1 gene has been used to determine whether an infection is a result of a new infection or a relapse [11] and used to genotype isolates of different strains from different geographical regions $[12,13,15-17]$. The polymorphic pvmsp3-alpha gene was also studied by polymerase chain reaction-restriction fragment length polymorphism (PCRRFLP) analysis $[19,20]$. The pumsp3-alpha gene encodes a merozoite surface protein with an alanine-rich central domain that is predicted to form a coiled-coil tertiary structure [21]. There is added interest in the pumsp 3 antigen family as immunogens and vaccine candidates. Use of the pumsp3-alpha gene as genetic marker has been recently validated $[19,20,24,30,39,40]$. Other genetic markers used for $P$. vivax are the apical membrane antigen 1 (Ama1 ), gametocyte antigen 1 (gam 1 ) and msp3-beta. The PvAma-1 is a protein essential for erythrocyte invasion, which shows limited sequence polymorphism [26,34].
The potential of pvgam 1 as a molecular marker for genotyping is compromised by artifacts associated with amplification of this region [29]. The pumsp3-beta gene is a member of a family of related merozoite surface proteins containing a central alanine-rich central region with significant genetic diversity $[22,30]$. Despite this high level of sequence diversity certain physical properties of the encoded protein are maintained, particularly the ability to form coiled-coil tertiary structure [22], which may limit genetic studies.

Studies using single or combined pvcs, pvms $p 1$ and pvmsp3alpha genotyping have assessed the genetic diversity of $P$. vivax isolates from various regions. A study on pvcs identified that the VK247 genotype was widely distributed and was the predominant form in Thai and Papua New Guinea isolates but its prevalence was much lower in Mexico [23]. Another study, by contrast, revealed that the VK210 type in dimorphic pucs gene was found in the majority of the parasites in Thai strains $[24,10]$. A recent single gene study of pumsp3-alpha revealed that it was highly polymorphic, and that three major types of the pumsp3-alpha locus could be distinguished $[32,39]$. Moreover earlier studies revealed a high prevalence of multiple genotype infection as determined by pums $p 3$-alpha [19] and pvcs genotyping [18]. Recently a combined pvcs and pumsp1 study showed a lower rate of multiple genotype infections than an earlier study and high polymorphism in Thai strains [28]. In hyperendemic areas, intragenic recombination and high genetic diversity have been reported in pvmsp 1 and pums 33 -alpha $[16,20,39]$. Even in hypoendemic areas, such as Thailand and Brazil [11], pvmsp 1 and pums $p 3$-alpha display high levels of diversity [24]. By contrast, relatively low genetic diversity of $p v m s p 1$ has been detected in the re-emerging vivax malaria focus in Korea [31]. Little is known about the genetic diversity among parasite populations in India, where most vivax malaria in the world occurs. Earlier studies carried out using isoenzyme typing was consistent with the random mating nature of vivax malaria isolates in India [27]. Recent studies on the polymorphism of pvcs, pvgam 1 and pvms 3 alpha in Indian isolates have revealed two types of pvcs and nine size variations of pvgam 1 and high polymorphism in the pumsp3 alpha gene [37]. Therefore, the highly polymorphic, single-copy, unlinked genes, pvcs, pums 1 and pumsp3-alpha were selected for this study of genetic diversity of $P$. vivax in Kolkata.

\section{Methods \\ Blood samples}

Venous blood samples were collected from patients with symptomatic $P$. vivax malaria $(\mathrm{n}=151)$ attending the malaria clinic in the Calcutta School of Tropical Medicine, India, between April 2003 and September 2004. All patients gave fully informed consent to participate in this 
study which was approved by the Ethics committee of the Faculty of Tropical Medicine, Mahidol University and also permitted by the Calcutta School of Tropical Medicine. The diagnosis of vivax malaria was made by examination of thin and thick blood smear. Patients with pregnancy, G6PD deficiency and any underlying haemolytic diseases, and aged below three years old were excluded. Chloroquine ( $25 \mathrm{mg}$ base $/ \mathrm{kg}$ ) either alone or in conjunction with a five- or fourteen-day regimen of primaquine $(15 \mathrm{mg}$ base/day), was given to the 151 patients; primaquine was given only to non-G6PD deficiency cases. G6PD tests were done at the Centre for Tropical Medicine and Parasitology. Blood samples were collected in EDTA tubes from patients with confirmed $P$. vivax infection and were stored at $-20^{\circ} \mathrm{C}$ until DNA extraction.

\section{DNA template preparation}

DNA was purified from $1 \mathrm{ml}$ of infected venous blood using a commercially available DNA extraction kit (QIAGEN, Germany) according to a procedure described previously [28].

\section{Amplification protocol}

A nested PCR approach was adopted following previously described procedures $[28,19]$. All amplification reactions were carried out in a total volume of $20 \mu \mathrm{L}$ in the presence of $10 \mathrm{mM}$ Tris- $\mathrm{HCl}, \mathrm{pH} 8.3,50 \mathrm{mM} \mathrm{KCl}, 250 \mathrm{nM}$ of each oligonucleotide primer, $125 \mu \mathrm{M}$ of each of the four dNTPs and 0.4 units of ampli-Taq polymerase (Invitrogen, USA). Primary amplification reactions were initiated with $1 \mu \mathrm{L}$ of the template genomic DNA prepared from the blood samples, and the $1 \mu \mathrm{L}$ of the product of these reactions was used to initiate the secondary amplification reaction. The PCR parameters were as follows: an initial denaturation step at $95^{\circ} \mathrm{C}$ for five minutes preceded the cycles of annealing at a temperature defined for each primer pair for two minutes, extension at $72^{\circ} \mathrm{C}$ for two minutes, and denaturation at $94^{\circ} \mathrm{C}$ for one minute. After a final annealing step followed by five minutes of extension, the reaction was terminated by reducing products temperature to $25^{\circ} \mathrm{C}$. PCR products were stored at $4{ }^{\circ} \mathrm{C}$ until analysis.

\section{Analysis of the amplification product}

The DNA fragments obtained from PCR were analyzed by electrophoresis in agarose gels. For direct analysis of the fragments, $10 \mu \mathrm{L}$ of the amplified PCR product were applied to $1.5 \%$ horizontal agarose gels for $p v c s, 2.0 \%$ for the second fragment of pumsp 1 and $1.0 \%$ for $p v m s p 3$-alpha at 120 volts. The size of the amplified DNA was estimated by comparing its mobility to a molecular weight marker. A 100 bp DNA ladder was used as a molecular weight marker in gel electrophoresis for pvcs and the second fragment of pumsp 1 but a $1 \mathrm{~kb}$ DNA ladder (Life and Technologies, U.S.A) was used as a molecular weight marker in the gel electrophoresis for pumsp3-alpha as this contains a
1900 bp DNA fragment. For restriction fragment length polymorphism analysis of the PCR products (PCR-RFLP), $10 \mu \mathrm{L}$ of the amplified PCR product were first digested with a restriction enzyme (New England Biolabs Inc, UK) for three hours in a total volume of $20 \mu \mathrm{L}$, before applying to $1.5 \%$ or $1.8 \%$ agarose gels. Electrophoresis was performed in TBE buffer, and the DNA was visualized on an ultraviolet transilluminator following ethidium bromide staining. For the purpose of this study, the frequency of an allele is calculated simply as its percentage of the total of all alleles detected among the isolates examined.

\section{Results}

\section{Genotyping of pvcs}

Amplification of the fragment containing the pvcs gene was attempted for blood samples obtained from patients. After two rounds of PCR, bands of $680-740$ bp were amplified. This nested PCR generated three product size variants (Table 1). All the allelic variants were ordered in decreasing sizes of base pairs and coded alphabetically, starting a to $\mathbf{c}$. The frequencies of type a (740 bp), type $\mathbf{b}$ (710 bp) and type c (680 bp) were $28 \%, 65 \%$ and $7 \%$, respectively (Figure 1 ). The most common allele was type b $(65 \% ; 97 / 151)$. Two cases of type a were mixed with type $\mathbf{b}$. There were two types of repeat region in the pvcs gene: the VK210 type of repeat unit coding for Gly-AspArg-Ala-Asp/Ala-Gly-Gln-Pro-Ala [41], and the VK247 type coding for repeats of Ala-Asn-Gly-Ala-Gly-Asn-GlnPro-Gly [10]. VK210 and VK247 were distinguished by digestion with the restriction enzymes, Alu1 and BstN1. In 151 samples 150 isolates were VK210 type and only one isolate was VK247 (Table 1).

PCR products were digested by $S c r F 1$, which recognizes insertion on $5^{\prime} \mathrm{CC} / \mathrm{NGG} 3$ ' restriction site in the pre repeated region and by Bbs 1 , which cuts the DNA on 5 'GAAGACNN/NN3' site in post repeated region. Therefore, there are four possible combinations in the VK210 type (no/in, no/no, in/in and in/no) but in VK247 type

Table I: Size and RFLP patterns and populations of pvcs alleles (n $=(51)$.

\begin{tabular}{cccc}
\hline Alleles & Size variation & Pre/Post patterns & $\mathrm{n}(\%)$ \\
\hline I. VK247 & $\mathrm{a}$ & in & $\mathrm{I}(0.66)$ \\
2. VK210 & $\mathrm{a}$ & in/in & $2(1.32 \%)$ \\
3. VK210 & $\mathrm{a}$ & no/in & $26(17.2 \%)$ \\
4. VK210 & $\mathrm{a}$ & no/no & $16(10.6 \%)$ \\
5. VK210 & $\mathrm{a}+\mathrm{b}$ & no/in & $2(1.32 \%)$ \\
6. VK210 & $\mathrm{b}$ & in/in & $4(2.64 \%)$ \\
7. VK210 & $\mathrm{b}$ & no/in & $48(31.7 \%)$ \\
8. VK210 & $\mathrm{b}$ & no/no & $45(29.8 \%)$ \\
9. VK210 & $\mathrm{c}$ & in/in & $1(0.66 \%)$ \\
10. VK210 & $\mathrm{c}$ & no/in & $2(1.32 \%)$ \\
II. VK210 & $\mathrm{c}$ & no/no & $5(3.3 \%)$ \\
& & &
\end{tabular}




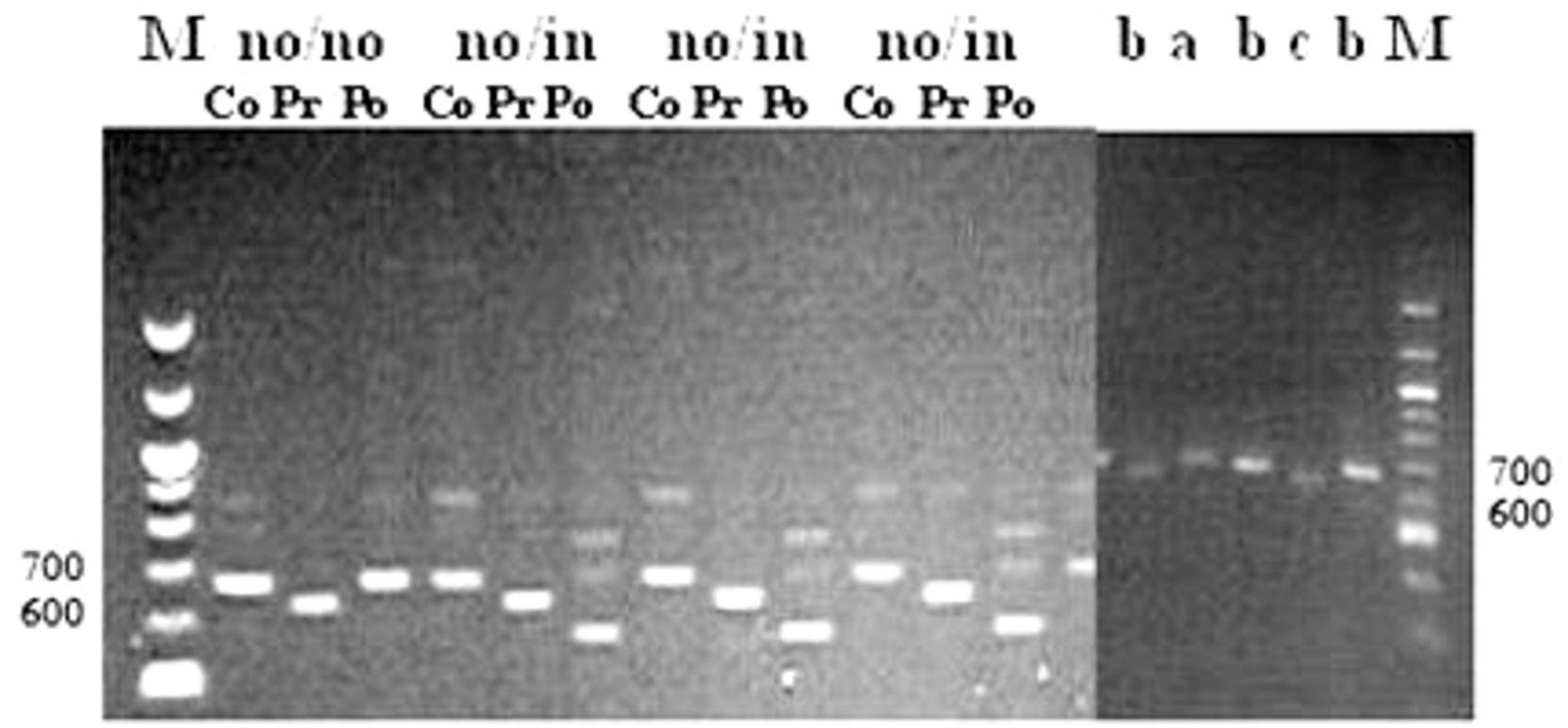

\section{Figure I}

The predominant two variants (no/no and no/in) of VK210 type of pvcs gene observed in the 150 isolates from Kolkata, India. $M$ is a 100 bp DNA ladder. Co and Pr and Po stand for control (nested PCR product), pre-repeat region digested by ScrFI enzyme and post-repeat region digested by Bbs I enzyme, respectively. The three size variants $\mathbf{a}, \mathbf{b}$ and $\mathbf{c}$ are 740, 7/0 and 680 bp, respectively.

two types were possible (in or no). Three variants were found in the samples (no/no, no/in, and in/in) and two of them (no/no and no/in) were predominant in the Kolkata strains (Figure 1). The frequencies of these were $43.7 \%$ for no/no and $51 \%$ for no/in respectively. Eleven alleles of pvcs (combinations of size variation and insertion presence/absence) were found in 151 isolates, and these were randomly distributed (Figure 2).

\section{Genotyping of pvmsp I}

The second fragment of pumsp 1 generated 1087-1150 bp from 151 samples.

Analysis on agarose gels revealed two different sizes, labeled $\mathbf{a}$ and $\mathbf{b}$. Despite the lack of variation in the size of the amplification products, RFLP analysis with Alu1 and Mnl1 restriction enzymes revealed substantial diversity at the nucleotide level. The RFLP patterns of different isolates showed variation in size. Digestion with either Alu 1 or $\mathrm{Mnl1}$ yielded fragment sizes that were highly polymorphic. From the 151 samples 8 different Alu 1 patterns and 5 different Mnl1 patterns were observed (Figure 3). When data from both analyses were combined, 35 alleles of the second fragment of pumsp 1 could be differentiated (Table 2).
The frequency distribution of the 35 alleles of the second fragment of pums $p 1$ is shown in Figure 4. It was found that alleles 1 (a a1 $\mathrm{m} 1)$ and 18 (b a1 m1), alleles 4 (a a2 m2) and 28 (b a5 $\mathrm{m} 4$ ) were particularly predominant (20 and 26, 17 and 16 respectively among 151 samples [13.2, $17.2,11.2$ and $10.6 \%$ respectively]). The remaining isolates were randomly distributed between the other variants.

\section{Genotyping of pvmsp3-alpha}

Amplification products showed a major size polymorphism with three different variants labelled $\mathbf{a}$, b and $\mathbf{c}$ (1900-1100 bp). These were predominantly of a size (102/151 [67.5\%]) (Figure 5). The frequencies of type a (1900 bp), type b (1500 bp) and type c (1100 bp) were $67.5 \%, 12.5 \%$ and $20 \%$ respectively. RFLP analysis with Alu 1 and Hha 1 restriction enzymes revealed substantial diversity at nucleotide level. Digestion with these enzymes yielded fragment sizes that were highly polymorphic. The sum of the fragment sizes did not always equal the size of the intact PCR product, indicating non-resolvable variation in size of the uncut amplification products but never more than the total size, thereby indicating a number of mixed genotypes. From the 151 samples, five different Alu 1 patterns and five different Hha 1 RFLP patterns were 


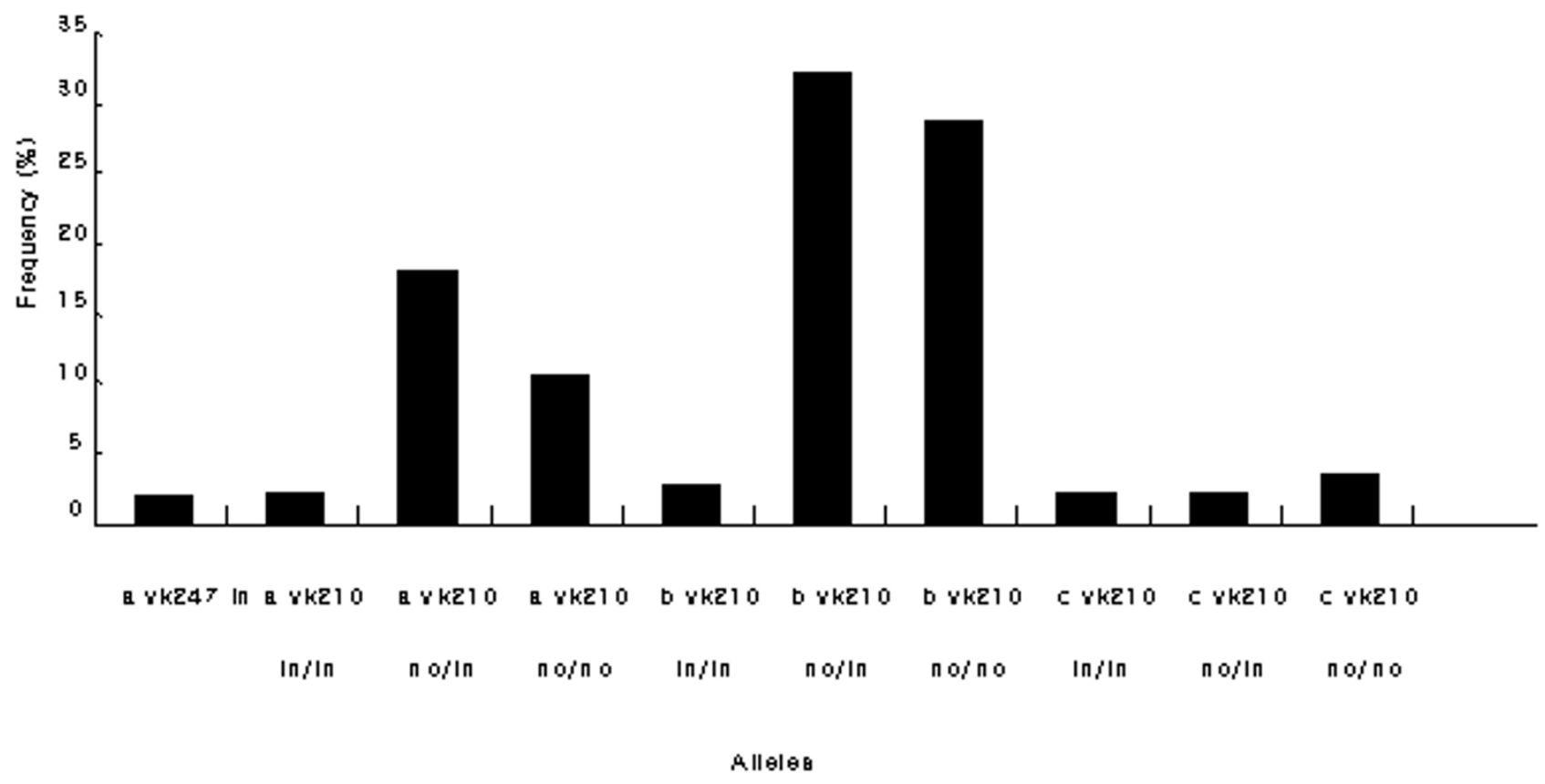

Figure 2

Allele frequency distribution of pvcs observed in the 15I Kolkata isolates.

observed. When data from both analyses were combined, 37 alleles of pvmsp3-alphacould be differentiated (Table 3 ). The frequency distribution of the 37 alleles of pvms $p 3$ - alpha alleles in 151 isolates is shown in Figure 6. Allele 1 (a al1 h1) was particularly dominant (22/151 [14.5\%]) and the others were randomly distributed.
A)

\section{$\begin{array}{llllllllllllll}4 & 5 & 6 & 2 & 3 & 2 & 3 & 2 & 2 & 7 & 7 & 1 & 1 & M\end{array}$}

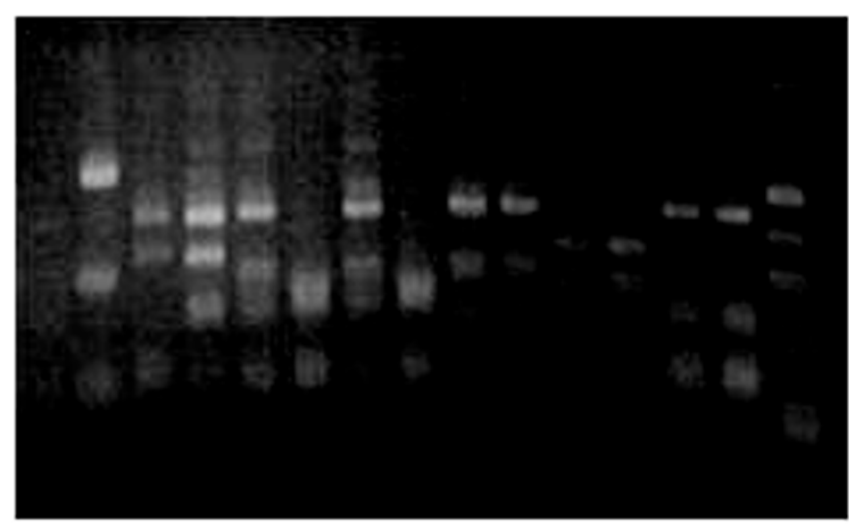

B)

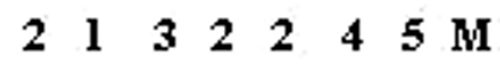

500

300

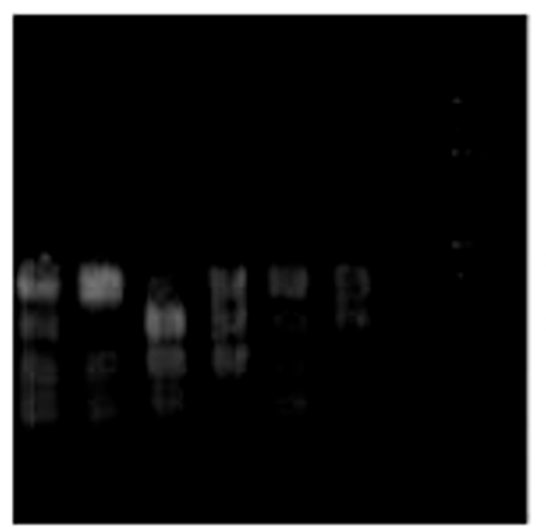

500

300

\section{Figure 3}

A) Dominant alleles by Alu / restriction enzyme digestion of the second fragment of pvmsp / gene. B) Dominant alleles by Mnll restriction enzyme digestion of the second fragment of pvmsp/ gene. $M$ is a DNA marker in 100 bp steps. 
Table 2: Size and RFLP patterns and frequency of pvmspl alleles detected (the second fragment) $(\mathrm{n}=\mid \mathbf{I} \mathrm{I})$.

\begin{tabular}{|c|c|c|c|c|}
\hline Alleles & Size variation & AluI RFLP patterns & Mnll RFLP patterns & $\mathrm{n}(\%)$ \\
\hline I & $\mathrm{a}$ & al & $\mathrm{ml}$ & $20(13.2 \%)$ \\
\hline 2 & $\mathrm{a}$ & al & $\mathrm{m} 2$ & $2(1.32 \%)$ \\
\hline 3 & $\mathrm{a}$ & a2 & $\mathrm{ml}$ & $3(2.0 \%)$ \\
\hline 4 & $\mathrm{a}$ & $\mathrm{a} 2$ & $\mathrm{~m} 2$ & $17(11.2 \%)$ \\
\hline 5 & $\mathrm{a}$ & a2 & $\mathrm{m} 4$ & $\mathrm{I}(0.66 \%)$ \\
\hline 6 & a & a2 & $\mathrm{m} 5$ & 1 \\
\hline 7 & $\mathrm{a}$ & a3 & $\mathrm{ml}$ & I \\
\hline 8 & $\mathrm{a}$ & a3 & $\mathrm{m} 6$ & 1 \\
\hline 9 & a & $\mathrm{a} 4$ & $\mathrm{ml}$ & I \\
\hline 10 & $\mathrm{a}$ & $\mathrm{a} 4$ & $\mathrm{~m} 2$ & I \\
\hline 11 & $\mathrm{a}$ & $\mathrm{a} 4$ & $\mathrm{~m} 4$ & I \\
\hline 12 & $\mathrm{a}$ & a5 & $\mathrm{m} 4$ & $6(4.0 \%)$ \\
\hline 13 & $\mathrm{a}$ & a5 & $\mathrm{m} 5$ & 1 \\
\hline 14 & $\mathrm{a}$ & a6 & $\mathrm{m} 4$ & 2 \\
\hline 15 & $\mathrm{a}$ & a6 & m5 & $13(8.6 \%)$ \\
\hline 16 & $\mathrm{a}$ & a7 & $\mathrm{m} 4$ & 1 \\
\hline 17 & $\mathrm{a}$ & a7 & $\mathrm{m} 5$ & 1 \\
\hline 18 & $b$ & al & $\mathrm{ml}$ & $26(17.3 \%)$ \\
\hline 19 & $\mathrm{~b}$ & al & $\mathrm{m} 2$ & $5(3.3 \%)$ \\
\hline 20 & b & $\mathrm{a} 2$ & $\mathrm{ml}$ & I \\
\hline 21 & b & a2 & $\mathrm{m} 2$ & 7 (4.6\%) \\
\hline 22 & $b$ & a3 & $\mathrm{ml}$ & I \\
\hline 23 & b & a3 & $\mathrm{m} 2$ & I \\
\hline 24 & $b$ & a3 & $\mathrm{m} 5$ & 1 \\
\hline 25 & $b$ & $\mathrm{a} 4$ & $\mathrm{ml}$ & 2 \\
\hline 26 & $\mathrm{~b}$ & a5 & $\mathrm{ml}$ & 1 \\
\hline 27 & $b$ & a5 & $\mathrm{m} 2$ & 2 \\
\hline 28 & b & a5 & $\mathrm{m} 4$ & $16(10.3 \%)$ \\
\hline 29 & $b$ & a6 & $\mathrm{ml}$ & I \\
\hline 30 & $b$ & a6 & $\mathrm{m} 2$ & 2 \\
\hline 31 & b & a6 & $\mathrm{m} 4$ & 4 (2.64\%) \\
\hline 32 & $b$ & a6 & $\mathrm{m} 5$ & 2 \\
\hline 33 & $b$ & a7 & $\mathrm{m} 4$ & I \\
\hline 34 & $b$ & a7 & $\mathrm{m} 6$ & 4 \\
\hline 35 & $b$ & a8 & $\mathrm{m} 5$ & 1 \\
\hline
\end{tabular}

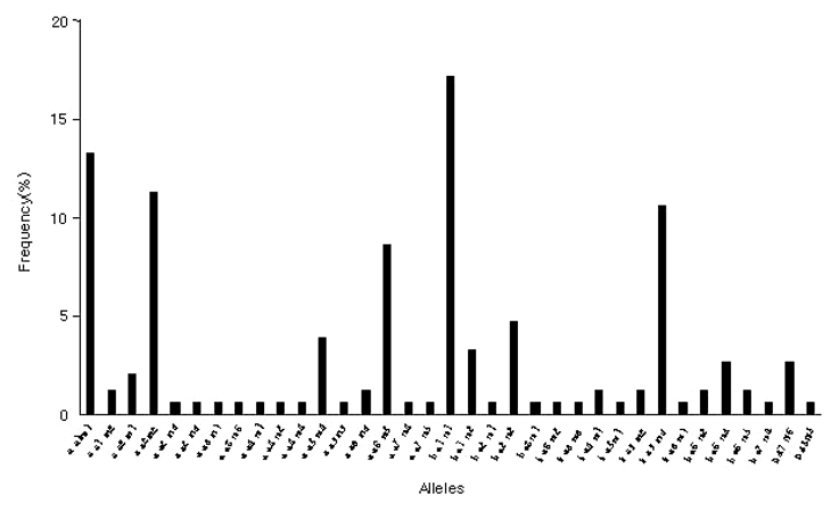

Figure 4

The allele frequency distribution of the second fragment of pvmsp I locus in the I5I Kolkata isolates characterized by a combination of fragment size and sequence type using RFLP.

\section{Analysis of three genes genotyping}

The results showed marked genetic diversity in the Kolkata strains with 11 alleles for pvcs, 35 alleles of the second fragment of pums $p 1$, and 37 alleles of pums 33 -alpha. Mixed genotypes of each marker were found in pvcs $1.3 \%$, pvms $p 1$ $0.7 \%$ and pumsp 3 -alpha $8.6 \%$. The overall rate of mixed gene infection was $10.6 \%$ using all three genetic markers. The most common alleles for each of the three genes were seen in $31.7 \%$ of samples for pvcs (allele7-bVK210 no/in), $17 \%$ of samples for the second fragment of pums 1 (allele18-b a $1 \mathrm{~m} 1$ ) and $14.5 \%$ for pumsp3 (allele1-a a11 ha1) (Figure 2, 4, and 6). Therefore, when genetically homogeneous parasite lines are considered in this area, the three markers can distinguish a potential 14,245 (11 × $35 \times 37)$ unique genotypes. In the combination of three genetic markers, The most common three marker genotype was b VK210 no/in, b a1 m1, c a1 h1 allele, which occurred at a rate of $2 \%(n=3 / 151)$. 


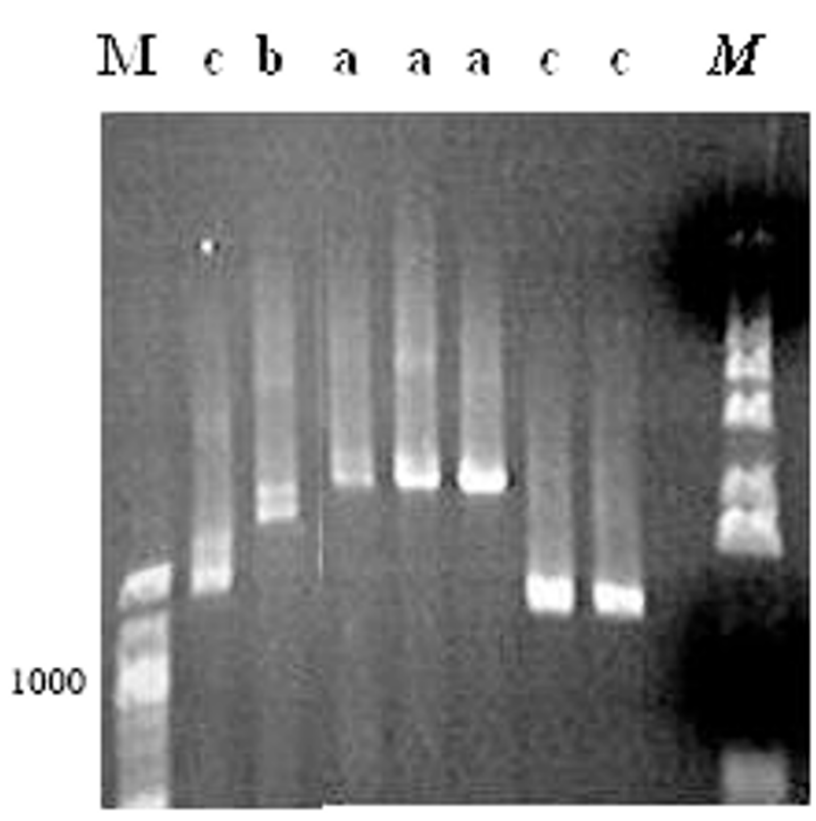

\section{Figure 5}

Three sizes of pvmsp3-alpha gene product in the I5I Kolkata isolates. The three sizes $\mathbf{a}, \mathbf{b}$ and $\mathbf{c}$ represented are 1900, 1500 and I 100 bp, respectively. $M$ is a 100 bp DNA ladder marker and $M$ is a I kb DNA ladder. Double bands reflect infection with multiple genotypes.

\section{Discussion}

The results showed that $P$. vivax parasites from Kolkata demonstrated an extremely high prevalence of VK210 type in the pvcs gene (with only one VK247 type), high polymorphism in both merozoite surface proteins (pvmsp1 and pvmsp3 alpha), and low rates (10.6\%) of multiple genotype infection.

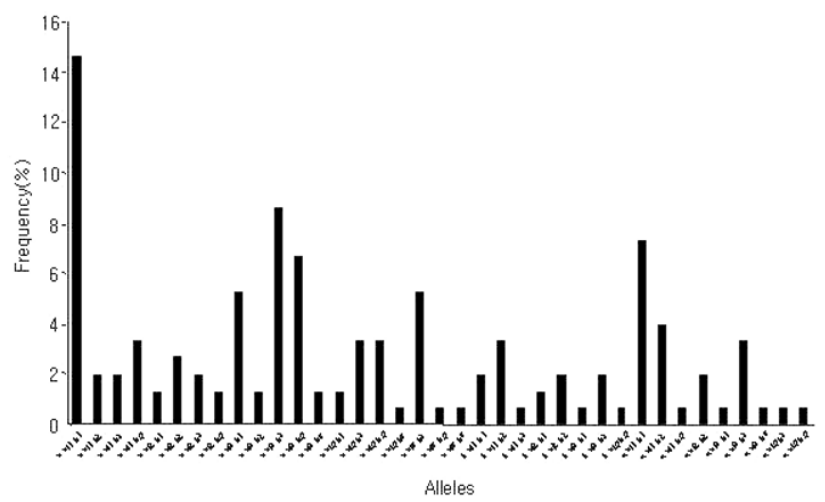

\section{Figure 6}

Frequency distribution of alleles at the pvmsp3-alpha loci observed in the 151 Kolkata isolates.
The predominance in Kolkata isolates of VK210 pvcs gene type (99.3\%) has not been seen elsewhere to the same extent. Recent studies in Thailand have found rates of $70.5 \%$ [35], 78\% [24] and 90\% [28], though these results were in sharp contrast to those of earlier studies in which VK247 was found to be the predominant type; $83 \%$ in Thai and $90 \%$ in Papua New Guinea samples by PCR/ Oligo Probe [23]. Another study of Indian strains has shown the VK210 type to be predominant, but also demonstrated (using a different technique) significant numbers of VK247 type [33]. This phenomenon may be attributed to selection by host immune pressure on a particular genotype, and/or the preferential production of sporozoites carrying a specific variant [18], such as VK210 for pvcs in a mosquito species. These differences may also be due to sampling biases or regional temporal fluctuations of individual genotypes frequencies. The frequency of absence of the pre-repeat insertion of VK210 in the pvcs gene was $4.7 \%(7 / 150)$ and that of the post-repeat region of the gene $56 \%(84 / 150)$ in Kolkata. In the absence of a multicentre study involving various regions of India it is difficult to define the extent to which the observed difference was in any way related to the functional aspects of the Kolkata strain.

In this study, two major types of the pumsp 1 marker containing 35 alleles were found. A similar degree of diversity (36 allelic types) was also found in the study from Thailand using the same laboratory protocol [28], and with a different protocol in Papua New Guinea and Indian strains $[16,42]$. For pumsp3-alpha, the present study reveals 37 alleles with three size variants cut by two restriction enzymes. The frequencies of the three pvmsp3-alpha types were consistent with those found in Papua New Guinea and Thailand $[18,19]$. A recent study using a different protocol revealed 16 size and sequence polymorphic allele in Indian strains [37]. This high degree of polymorphism in the merozoite surface protein (pvmsp1 and pvmsp3-alpha) is similar to that found in other studies from other regions.

All three markers show marked genetic diversity in Kolkata strains, with 11 alleles for pvcs, 35 alleles for the second fragment of pvmsp1, and 37 alleles for pvmsp3-alpha. This compares with another study of Indian vivax isolates which revealed 2 sequence variants of pvcs, 9 size variants in pvgam 1 , and 16 size variants with sequence polymorphism in pvmsp3-alpha gene [37].

The frequency of multiple genotype infections of $P$. vivax malaria has been estimated in many regions but it is difficult to compare these values due to differences in sampling and genotyping methods. The proportion of mixed gene infections estimated in Papua New Guinea, India, and Thailand ranges from $30 \%$ to $65 \%[16,20,24,25]$. The 
Table 3: Size and RFLP patterns and frequency of pvmsp3-alpha alleles detected $(n=\mid 51)$.

\begin{tabular}{|c|c|c|c|c|}
\hline Alleles & Size variation & Alu I RFLP patterns & Hhal RFLP patterns & $\mathrm{n}(\%)$ \\
\hline I & $\mathrm{a}$ & al I & hl & $22(14.5 \%)$ \\
\hline 2 & $\mathrm{a}$ & al I & h2 & 3 \\
\hline 3 & $\mathrm{a}$ & al I & h3 & 3 \\
\hline 4 & $\mathrm{a}$ & al I & h4 & $5(3.3 \%)$ \\
\hline 5 & a & al 2 & hl & 2 \\
\hline 6 & $\mathrm{a}$ & al 2 & h2 & 4 \\
\hline 7 & $\mathrm{a}$ & al 2 & h3 & 3 \\
\hline 8 & a & al 2 & h4 & 2 \\
\hline 9 & $\mathrm{a}$ & al 3 & hl & $8(5.2 \%)$ \\
\hline 10 & $\mathrm{a}$ & al 3 & h2 & 2 \\
\hline II & $\mathrm{a}$ & al 3 & h3 & $13(8.6 \%)$ \\
\hline 12 & $\mathrm{a}$ & al 3 & h4 & $10(6.6 \%)$ \\
\hline 13 & $\mathrm{a}$ & al 3 & h5 & 2 \\
\hline 14 & $\mathrm{a}$ & al 4 & hl & 2 \\
\hline 15 & $\mathrm{a}$ & al 4 & h3 & 5 \\
\hline 16 & a & al 4 & h4 & 5 \\
\hline 17 & $\mathrm{a}$ & al 4 & h5 & I \\
\hline 18 & $\mathrm{a}$ & al 5 & h3 & $8(5.2 \%)$ \\
\hline 19 & $\mathrm{a}$ & al 5 & h4 & I \\
\hline 20 & $\mathrm{a}$ & al 5 & h5 & I \\
\hline 21 & $b$ & al I & hl & 3 \\
\hline 22 & b & al I & h2 & 5 \\
\hline 23 & $b$ & al I & h3 & I \\
\hline 24 & $b$ & al 2 & hl & 2 \\
\hline 25 & $b$ & al 2 & h2 & 3 \\
\hline 26 & b & al 3 & hl & 1 \\
\hline 27 & b & al 3 & h3 & 3 \\
\hline 28 & $b$ & al 4 & h4 & I \\
\hline 29 & c & al I & hl & II (7.2\%) \\
\hline 30 & c & al I & h2 & $6(4.0 \%)$ \\
\hline 31 & c & al I & $\mathrm{h} 4$ & I \\
\hline 32 & c & al 2 & h2 & 3 \\
\hline 33 & c & al 3 & hl & 1 \\
\hline 34 & c & al 3 & h3 & 5 \\
\hline 35 & c & al 3 & h5 & 1 \\
\hline 36 & c & al 4 & h3 & I \\
\hline 37 & c & al 4 & h4 & 1 \\
\hline
\end{tabular}

present study with a relatively large sampling size, shows an overall $10.6 \%$ for multiple genotypes $(1.3 \%$ for pvcs, $0.7 \%$ for $p v m s p 1$ and $8.6 \%$ for pums $p 3$ alpha). This rate may reflect a limitation in the sensitivity of PCR for the detection of multiple genotype infections, despite the high degree of polymorphism seen.

According to the Calcutta School of Tropical Medicine Report 2005, the malaria clinic treats around 6,000 malaria positive cases annually, of which an average of $65 \%$ are caused by $P$. vivax. The rate of mixed infection with both $P$. vivax and $P$. falciparum during the last few years has declined $(1.0 \%$ in $1997,0.7 \%$ in 1998 and $0.1 \%$ in 2001) [6]. The samples from Kolkata were collected from an urban area where vivax malaria remains chloro- quine-sensitive, but where recurrences are frequent. Only a few cases were contracted outside of central Kolkata. The high degree of polymorphism and low level of multiple genotype infection probably reflects the nature of this endemic setting. More study is needed to assess whether these discrepancies reflect true differences between disease populations, or are due to differences in sample sizes or the laboratory methodology $[20,38]$.

\section{Conclusion}

When genotyped using three polymorphic markers (pvcs, pumsp1 and pumsp3-alpha)P. vivax infections in Kolkata demonstrate a low rate of multiple genotype infection despite a high degree of genetic diversity. Given the degree of diversity found genotyping methods such as these are 
likely to be of value in distinguishing relapse/recurrence from reinfection in clinical trials of antimalarial drug efficacy.

\section{Authors' contributions}

JRK was involved in all stages of this study. SP and AN designed the study and were responsible for the day-today supervision of patient recruitment and clinical management. MI was responsible for the supervision of the molecular genetic study and NT for the laboratory work. $\mathrm{AM}$ and MA participated in the recruiting of patients. KC and APN participated in the coordination of laboratory work. NJW and NPD helped compose the manuscript and gave constructive advice. All authors read and approved this final manuscript.

\section{Acknowledgements}

We thank Kasia Stepniewska for statistical advice. Some laboratory tests were done at the Centre of Tropical Medicine and Parasitology, Kolkata. This study was part of the Wellcome Trust-Mahidol University, Oxford Tropical Medicine Research Programme funded by the Wellcome Trust of Great Britain. Financial support was provided by a Wellcome Trust fellowship to MI (reference No. 066439/2/0I/2).

\section{References}

I. Pukrittayakamee S, Chantra A, Simpson JA, Vanijanonta S, Clemens R, Looareesuwan S, White NJ: Therapeutic responses to different antimalarial drugs in vivax malaria. Antimicrob Agents Chemother 2000, 44: 1680-1685

2. Mendis K, Sina BJ, Marchesiri P, Carter R: The neglected burden of Plasmodium vivax malaria. Am J Trop Med Hyg 200I, 64:97- 106.

3. Dua VK, Kar PK, Sharma VP: Chloroquine resistant Plasmodium vivax malaria in India. Trop Med Int Heath 1996, I:816-819.

4. Rieckmann KH, David DR, Hutton DC: Plasmodium vivax resistance to chloroquine? Lancet 1989, 2: | | 183-1 I84.

5. Baird JK, Basri H, Purnomo, Bang MJ, Subianto B, Patchen LC, Hoffman SL: Resistance to chloroquine by Plasmodium vivax in Irian Jaya, Indonesia. Am J Trop Med Hyg |99|, 44:547-552.

6. Nandy A, Addy M, Maji AK, Bandypadhyay AK: Monitoring the chloroquine sensitivity of Plasmodium vivax from Calcutta and Orissa, India. Ann Trop Med Parasitol 2003, 97:215-220.

7. Adak T, Sharma VP, Orlov VS: Studies on the Plasmodium vivax relapse pattern in Delhi, India. Am J Trop Med Hyg 1998, 59:175-179.

8. Singh N, Mishra SS, Singh MP, Sharma VP: Seasonality of Plasmodium vivax and $P$. falciparum in tribal villages in central India (1987-1995). Ann Trop Med Parasitol 2000, 94:101-II2.

9. Viriyakosol S, Siripoon N, Petcharapirat C, Petcharapirat P, Jarra W, Thaithong S, Brown KN, Snounou G: Genotyping of plasmodium falciparum isolates by the polymerase chain reaction and potential uses in epidemiological studies. Bull World Health Organization 1995, 73:85-95.

10. Rosenberg R, Wirtz RA, Lanar DE, Sattabongkot J, Hall T, Waters AP, Prasittisuk C: Circumsporozoite protein heterogeneity in human malaria parasite Plasmodium vivax. Science 1989, 245:973-976.

II. Kirchgatter K, del Portillo HA: Molecular analysis of Plasmodium vivax relapse using the MSPI molecule as a genetic marker. $J$ Infect Dis 1998, 177:5। I-5।5.

12. Del Portillo HA, Longacre S, Khouri E, David PH: Primary structure of the merozoite surface antigen I of Plasmodium vivax reveals sequences conserved between different Plasmodium species. Proc Natl Acad Sci USA 199I, 88:4030-4034.

13. Premawansa S, Snewin VA, Khouri E, Mendis KN, David PH: Plasmodium vivax : recombination between potential allelic types of the merozoite surface protein MSPI in parasites isolated from patients. Exp Parasitol 1993, 76:192-199.
14. Snounou G, Zhu X, Siripoon N, Jarra W, Thaithong S, Brown KN, Viriyakosol S: Biased distribution of $\mathrm{mspl}$ and $\mathrm{msp} 2$ allelic variants in Plasmodium falciparum populations in Thailand. Trans $R$ Soc Trop Med Hyg 1999, 93:369-374.

15. Gibson HL, Tucker JE, Kaslow D, Krettli AU, Collins WE, Kiefer MC, Bathurst IC, Barr PJ: Structure and expression of gene for Pv200, a major blood-stage antigen of Plasmodium vivax. Mol Biochem Parasitol 1992, 50:325-334.

16. Kolakovich KA, Ssengoba A, Wojcik K, Tsuboi T, al Yaman F, Alpers $\mathrm{M}$, Adams JH: Plasmodium vivax : favored gene frequencies of merozoite surface protein- $I$ and the multiplicity of infection in a malaria endemic region. Exp Parasitol 1996, 83: I I-19.

17. Putaporntip C, Jongwuitiwes S, Tanabe K, Thaithong S: Interallelic recombination in the merozoite surface protein I(MSPI) gene of Plasmodium vivax from Thai isolates. Mol Biochem Parasitol 1997, 84:49-56.

18. Cui L, Escalante AA, Imwong M, Snounou G: The geneticdiversity of Plasmodium vivax populations. Trends Parasitol 2003, 19:220-226

19. Bruce MC, Galinski MR, Barnwell JW, Snounou G, Day KP: Polymorphism at the merozoite surface protein-3 alpha locus of Plasmodium vivax; global and local diversity. Am J Trop Med Hyg 1999, 61:518-525.

20. Bruce MC, Galinski MR, Barnwell JW, Donnelly CA, Warmsley M, Alpers MP, Walliker D, Day KP: Genetic diversity and dynamics of Plasmodium falciparum and $P$. vivax populations in multiply infected children with asymptomatic malaria infections in Papua New Guinea. Parasitology 2000, I 2 1:252-272.

21. Galinski MR, Corredor-Medina C, Povoa M, Crosby J, Ingravallo P, Barnwell JW: Plasmodium vivax merozoite surface protein-3 contains coiled-coil motifs in an alanine-rich central domain. Mol Biochem Parasitol 1999, 101:131-147.

22. Rayner JC, Huber CS, Feldman D, Ingravallo P, Galinski MR, Barnwell $\mathrm{JW}$ : Plasmodium vivax merozoite surface protein PvMSP-3 beta is radically polymorphic through mutation and large insertions and deletions. Infection, Genetics and Evolution 2004, 4:309-319.

23. Kain KC, Brown AE, Webster HK, Wirtz RA, Keystone JS, Rodriguez $\mathrm{MH}$, Kinahan J, Rowland M, Lanar DE: Circumsporozoite genotyping of global isolates of Plasmodium vivax dried blood specimens. J Clin Microbiol 1992, 30:1863-1866.

24. Cui L, Mascorro CN, Fan Q, Rzomp KA, Khuntirat B, Zhou G, Chen $H$, Yan G, Sattabongkot J: Genetic diversity and multiple infections of Plasmodium vivax malaria in Western Thailand. $\mathrm{Am} J$ Trop Med Hyg 2003, 68:613-619.

25. Joshi H, Subbarao SK, Adak T, Nanda N, Ghosh SK, Carter R, Sharma VP: Genetic sturucture of Plasmodium vivax isolates in India. Trans R Soc Trop Med Hyg 1997, 9 I:23I-235.

26. Cheng $Q$, Saul $A$ : Sequence analysis of the apical membrane antigen I (AMA-I) of Plamodium vivax. Mol Biochem Parasitol 1994, 65:183-187.

27. Joshi H, Subbarao SK, Raghavendra K, Sharma VP: Plasmodium vivax: Enzyme polymorphism in isolates of Indian origin. Trans R Soc Trop Med Hyg 1989, 83: 179-181.

28. Imwong M, Pukrittayakamee S, Gruner AC, Renia L, Letourneur F, Looareesuwan S, White NJ, Snounou G: Practical PCR genotyping protocols for Plasmodium vivax using Pvcs and Pvmspl. Malar J 2005, 4:20.

29. Imwong M, Pukrittayakamee S, Looareesuwan S, Poirriez J, Pasvol G, White NJ, Snounou G: Plasmodium vivax : polymerase chain reaction amplification artifacts limit the suitability of pvgam I as genetic marker. Exp Parasitol 200I, 99:175-179.

30. Galinski MR, Ingravallo P, Corredor-Medina C, Al-Khedery B, Povoa $M$, Barnwell JW: Plasmodium vivax merozoite surface proteins3beta and -3gamma share structual similarities with $P$. vivax merozoite surface protein-3 alpha and define a new gene family. Mol Biochem Parasitol 200I, I I 5:4 I-53.

31. Lim CS, Kim SH, Kwon SI, Song JW, Song KJ, Lee KN: Analysis of Plasmodium vivax merozoite surface protein-I gene sequences from resurgent Korean isolates. Am J Trop Med Hyg 2000, 62:26I-265.

32. Mascorro CN, Zhao K, Khuntirat B, Sattabongkot J, Yan G, Escalante $A A, C u i \mathrm{~L}$ : Molecular evolution and intragenic recombination of the merozoite surface protein MSP-3 alpha from the malaria parasite Plasmodium vivax in Thailand. Parasitology 2005, I $31: 25-35$. 
33. Kain KC, Keystone J, Franke ED, Lanar DE: Global distribution of a variant of the circumsporozoite gene of Plasmodium vivax. J Infect Dis 1991, 164:208-210.

34. Figtree M, Pasay CJ, Slade R, Cheng Q, Cloonan N, Walker J, Saul A: Plasmodium vivax synonymous substitution frequencies, evolution and population structure deduced from diversity in AMAI and MSPI genes. Mol Biochem Parasitol 2000, 108:53-66.

35. Suwanabun N, Sattabongkot J, Wirtz RA, Rosenberg R: The epidemiology of Plasmodium vivax circumsporozoite protein polymorphics in Thailand. Am J Trop Med Hyg 1994, 50:460-464.

36. Adak T, Valecha N, Sharma VP: Plasmodium vivax polymorphism in a clinical drug trial. Clin Diagn Lab Immun 200I, 8:89I-894.

37. Joshi $H$ : Markers for population genetic analysis of human plasmodia species, $\mathbf{P}$ falciparum and P.vivax. J Vector Borne Dis 2003, 40:78-83.

38. Cochrane AH, Nardin EH, de Arruda M, Maracic M, Clavijo P, Collins WE, Nussenzweig RS: Widespread reactivity of human sera with a variants repeat of the circumsporozoite protein of Plasmodium vivax. Am J Trop Med Hyg 1990, 43:446-45I.

39. Rayner JC, Corredor V, Feldman D, Ingravallo $P$, Iderabdullah $F$, Galinski MR, Barnwell JW: Extensive polymorphism in the Plasmodium vivax merozoite surface coat protein MSP-3 alpha is limited to specific domains. Parasitology 2002, 125:393-405

40. Bruce MC, Donnelly CA, Alpers MP, Galinski MR, Barnwell JW, Walliker D, Day KP: Cross-species interactions between malaria parasites in humans. Science 2000, 287:845-848.

4I. Arnot DE, Barnwell JW, Tam JP, Nussenzweig V, Nussenzweig RS, Enea V: Circumsporozoite protein of Plasmodium vivax : gene cloning and characterization of the immunodominant epitope. Science 1985, 230:815-818.

42. Maestre A, Sunil S, Ahmad G, Mohmmed A, Echeverri M, Corredor $M$, Blair S, Chauhan VS, Malhotra P: Inter-allelic recombination in the Plasmodium vivax merozoite surface protein I gene among Indian and Colombian isolates. Malar J 2004, 3:4.

\section{Publish with Bio Med Central and every scientist can read your work free of charge}

"BioMed Central will be the most significant development for disseminating the results of biomedical research in our lifetime. "

Sir Paul Nurse, Cancer Research UK

Your research papers will be:

- available free of charge to the entire biomedical community

- peer reviewed and published immediately upon acceptance

- cited in PubMed and archived on PubMed Central

- yours - you keep the copyright

Submit your manuscript here:

http://www.biomedcentral.com/info/publishing_adv.asp
BiolMedcentral 